Chapter 2

\title{
Analysis of Production and Consumption of Organic Products in South Africa
}

\author{
Maggie Kisaka-Lwayo and Ajuruchukwu Obi \\ Additional information is available at the end of the chapter \\ http://dx.doi.org/10.5772/58356
}

\section{Introduction}

Food and nutritional security remain an issue of global concern especially in developing countries. The practice of organic agriculture has been identified as a pathway to sustainable development and enhancing food security. Arguably, the most sustainable choice for agricultural development and food security is to increase total farm productivity in situ, in developing countries particularly sub-Saharan Africa. Attention must focus on the following: (i) the extent to which farmers can improve food production and raise incomes with low-cost, locallyavailable technologies and inputs (this is particularly important at times of very high fuel and agro-chemical prices); (ii) whether they can do this without causing further environmental damage; and (iii) the extent of farmers' ability to access markets [1]. Organic farming is one of the sustainable approaches to farming that can contribute to food and nutritional security [2]. Driven by increasing demand globally, organic agriculture has grown rapidly in the past decade [3]. Policy makers at the primary end of the food chains must wrestle with the dual objective of reducing poverty and increasing the flow of ecosystem services from rural areas occupied by small scale farmers and/or family farms [4].

Expectedly, a paradigm shift towards this realization of organic agriculture's role in food and nutritional security is emerging [5]. The United Nations Environmental Programme-United Nations Conference on Trade and Development, UNEP-UNCTAD [6] indicates that organic agriculture offers developing countries a wide range of economic, environmental, social and cultural benefits. On the development side, organic production is particularly well-suited for smallholder farmers, who make up the majority of the worlds' poor. Resource poor farmers are less dependent on external resources, experience higher yields on their farms and enjoy enhanced food security [7]. Organic agriculture in developing countries builds on and keeps alive their rich heritage of traditional knowledge and traditional land races. It has been 
observed to strengthen communities and give youth incentive to keep farming, thus reducing rural-urban migration. Farmers and their families and employees are no longer exposed to hazardous agro-chemicals, which is one of the leading causes of occupational injury and death in the world [7].

As organic production increases, so does the interest in organic market dynamics and studies are being carried out in order to analyse the future potential for organic agriculture. Figure 1 shows the global markets for certified organic products. In 2009, the global market for certified organic food and drink was estimated to be 54.9 billion US dollars [8]. This represents a $37 \%$ growth from 2006 sales estimated at 40. 2billionUS dollars and a 207\% increase from year 2000 sales estimated at17. 9 billion US dollars. In Africa, most of the organic farms are small family smallholdings [9] and certified organic production is mostly geared to products destined for export beyond Africa's shores. However, local markets for certified organic products are growing, especially in Egypt, South Africa, Uganda and Kenya [10]. Figure2 shows the ten countries in Africa with the largest proportion of land allocated to organic agriculture. South Africa has the third largest area under organic farming with 50, 000 hectares (ha), trailing Tunisia which has the largest area of 154, 793ha and Uganda with 88, 439ha [11]. Approximately $20 \%$ of the total area under certified organic farming in Africa is in South Africa, with 250 certified commercial farms [12]. With a few exceptions, notably Uganda, most African countries do not have data collection systems for organic farming and certified organic farming is relatively underdeveloped, even in comparison to other low-income continents. Some expert opinions suggest that this is due to lack of awareness, low-income levels, lack of local organic standards and other infrastructure for local market certification [13].

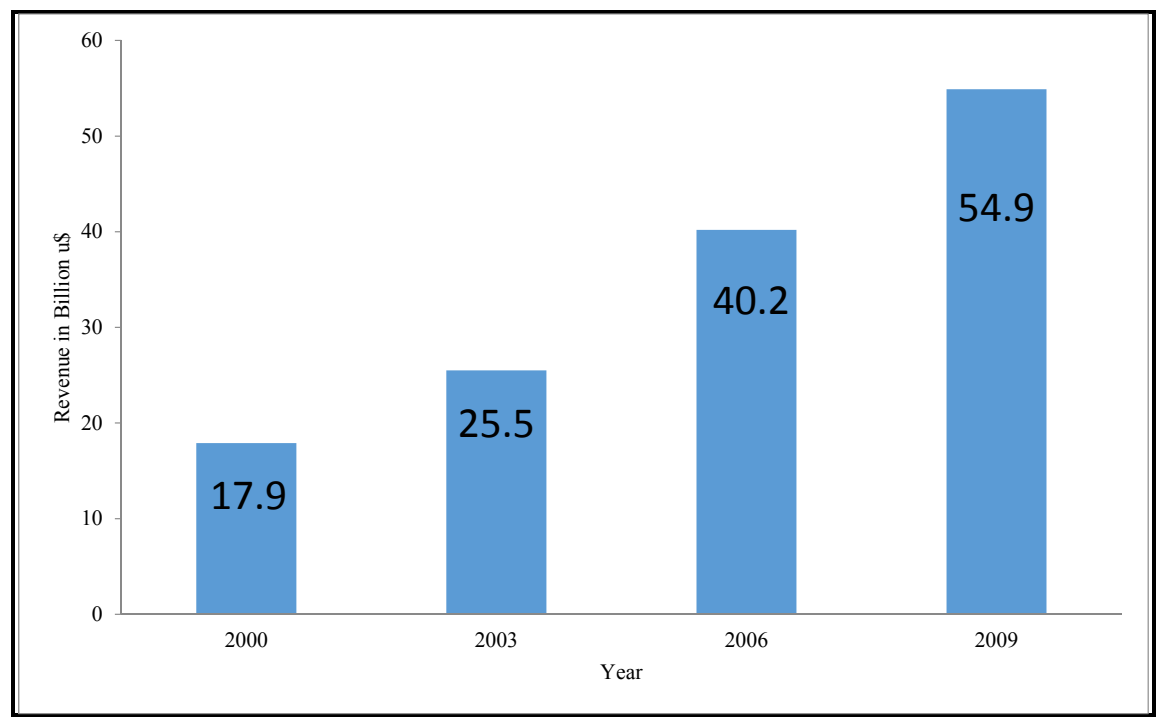

Figure 1. Development of the global market for organic products 


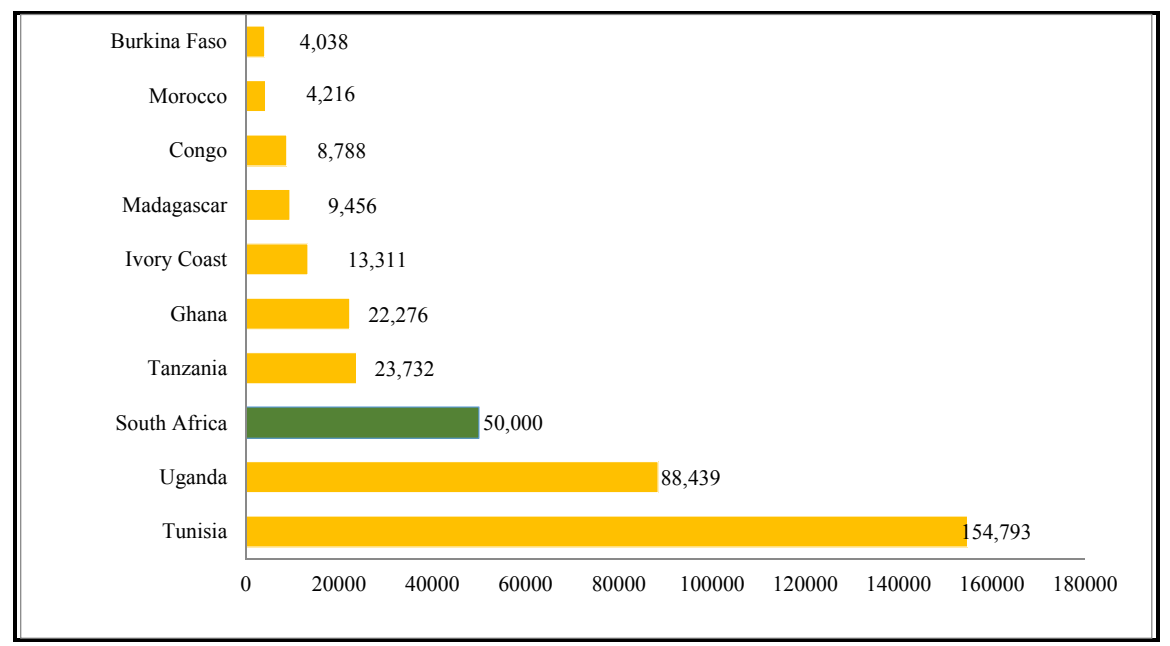

Source: [14]

Figure 2. The ten countries in Africa with the most organic agricultural land in hectares

\section{Organic agriculture in South Africa}

In 1999, only 35 farms were certified in South Africa, whereas in 2000 this number had increased to approximately 150 [15]. GROLINK [16] estimates that 240 farms with a total area of 43620 ha (including pastures and in-conversion land) were certified in 2002. Certified organic produce in South Africa started with mangoes, avocadoes, herbs, spices, rooibos tea and vegetables [17]. This has now expanded to include a much wider range of products. Organic wines, olive oil and dairy products are now being produced [18]. The Organic Agricultural Association of South Africa (OAASA) estimates that there are approximately 100 non-certified farmers, farming about 1000 hectares, following organic principles, who market informally through local villages or farmers markets (ibid). In the latter case, no differentiation is made between organic and non-organic produce.

South Africa has had an organic farming movement dating back many years, although it has grown in "fits and starts" [19]. Organic approaches have to make a trade off between market oriented commercial production and increasing the productive capacity of marginalized communities [20]. The growth of the organic industry has resulted in organic farming being practised in the Western Cape, KwaZulu-Natal, Eastern Cape, Northern Cape and Gauteng Province (Table 1). As discussed by [21] and [22] changing consumer preferences towards more health and environmental awareness has led to an increase in the demand for products produced using sustainable production methods. GROLINK [16] states that South Africa has in contrast with other Sub-Saharan countries, a substantial domestic market for organic 
products. This is an indication that the potential for organic farming in South Africa is not only based on access to the export market in Europe and the USA but also on the local demand. The domestic market is robust with two domestic retailers (Woolworth and Pick ' $n$ ' Pay) selling reasonable amounts of organic produce and both are now starting to insist on certification for this produce as well as farmers markets attracting large number of buyers.

One approach taken to improve smallholder access to organic markets has been the formation of certified organic groups using guidelines developed by the International Federation of Organic Agriculture Movement (IFOAM) and enforced by certification agencies such as Ecocert/AFRISCO (African Farmers Certified Organic) in the case of South Africa [23]. Under the group certification system, organic farmers can either grow and market their produce collectively or produce individually but market collectively. This ensures that smallholder farmers especially in developing countries are not marginalised and unduly excluded from the organic sector due to factors beyond their control. Several organic farming groups have emerged in South Africa in the last decade notably Ezemvelo Farmers Organization (EFO), Vukuzakhe Organic Farmers Organization (VOFO), Ikusasalethu Trust and Makhuluseni Organic Farmers Organisation.

The question of how to face the growing problem of food insecurity in Africa becomes more and more important, especially due to the steadily increasing world population and the changing consumption pattern. According to [24], while organically produced food seems not to be able to feed the World's Population, there are strong evidences that organic agriculture might help to alleviate the number of people suffering from hunger especially in developing countries. Given the strong negative externalities of conventional agriculture, the diversification of production as a basic principal of organic agriculture can contribute to the improvement of food security [25] which may improve the nutritional level in rural communities. The expanding global market for organic products $[26,27]$ and the possibilities for smallholder farmers in developing countries to access markets [24] can have very positive effects on the rural economies, triggering rural development. The increasing awareness of what people consume also has positive effects on organic agriculture as an alternative option for agricultural production. Organic agriculture may thus be an option in some areas to strongly support rural development.

Against this background, the objective of this paper is to provide, through an exploratory analysis of data from farm and households surveys, empirical insights into determinants of organic farming adoption, differentiating between fully-certified organic, partially-certified organic and non-organic farmers; eliciting farmers risk preferences and management strategies and; exploring consumer awareness, perceptions and consumption decisions. By exploring a combination of adoption relevant factors in the context of real and important land management choices, the paper provides an empirical contribution to the adoption literature and provides valuable pointers for the design of effective and efficient public policy for on-farm conservation activities. Similarly, achieving awareness and understanding the linkage between awareness and purchasing organics is fundamental to impacting the demand for organically grown products. Consumer awareness of organic foods is the first step in developing demand for organic. Section 3 describes the materials and methods, outlining the study areas and study 
methodology. Section 4 presents the results and discussion. Finally, section5 provides concluding remarks.

\section{Materials and methods}

The study was carried out in the two provinces of KwaZulu-Natal and the Eastern Cape Provinces in South Africa (Figure 3). The selected study areas are in the rural Umbumbulu Magisterial District in KwaZulu-Natal Province and the OR Tambo and Amatole District Municipalities in the Eastern Cape Province.

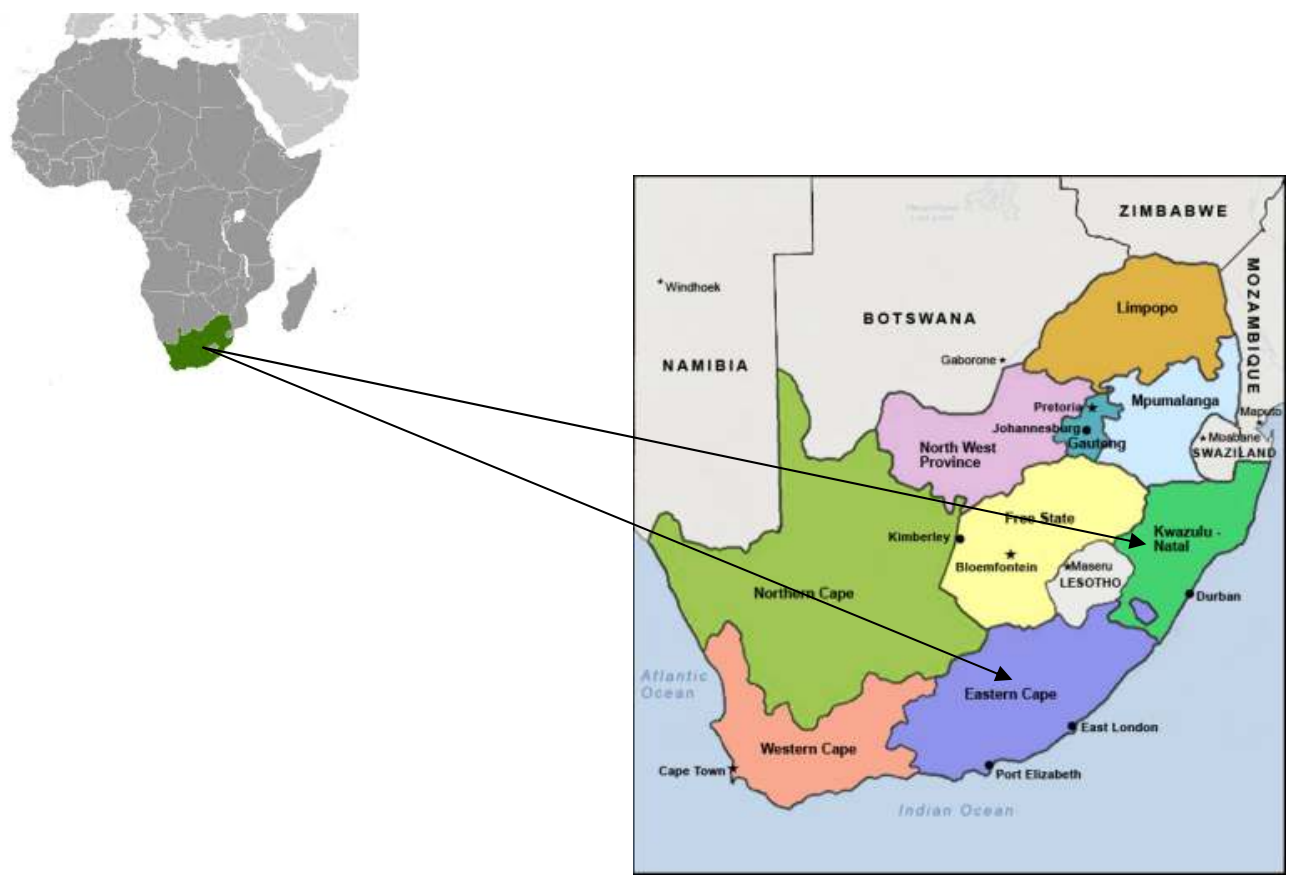

Figure 3. Map of study area

The Umbumbulu area is one of the former homelands of KwaZulu-Natal Province. The Province has the largest concentration of people who are relatively poor, and social indicators point to below average levels of social development. According to the mid-year population estimates by Statistics South Africa [28], the Province has a population of 10. 6 Million people 67 percent of whom reside in communal areas of the former KwaZulu-Natal homeland [28]. The OR Tambo District Municipality is the second poorest Municipality in the Eastern Cape Province with some areas having poverty levels of as high as $82 \%$ [29]. About $67 \%$ of the 
households within the district have income levels that range between R0 and R6, 000. The District Municipality has the second highest population of all the districts with more than 1, 504, 411 inhabitants [29]. For a mostly rural district it also has a high population density of 90 people per square kilometre. The Amatole District Municipality is named after the legendary Amatole Mountains and is the most diverse District Municipality in the Province. Two-thirds of the District is made up of ex-homeland areas. The District has a moderate Human Development Index of 0.52 with over 1, 635, 433 inhabitants [30], and a moderately high population density of 78 people per square kilometre. The population is mainly African with some whites and coloureds. Amatole District Municipality has the second highest economy in the province.

The Eastern Cape Province is bordering KwaZulu-Natal with similarities in the socio-economic status and rurality of the two Provinces. Both Provinces' economic dependence is on agriculture with huge potential for organic agriculture development. The Eastern Cape is also a major consumer of produce from KwaZulu-Natal. A total of 400 respondents were interviewed, representing 200 farmer respondents from KwaZulu-Natal and 200 consumer respondents from Eastern Cape Provinces. The survey farmers in Umbumbulu District, KwaZulu-Natal were stratified into three groups: fully-certified organic farmers, partially-certified organic farmers and non-organic farmers. While the 48 fully-certified farmers and 103 partiallycertified farmers were purposively selected, the sample of 49 non-organic farmers was randomly selected within the same region from a sample frame constructed from each of the five neighbouring wards. The survey was conducted by a team of trained enumerators from the study area. These enumerators had to be fluent in both English and Zulu. A questionnaire was used to record all household activities (farm and non-farm), enterprise types, crop areas and production levels, inputs, expenditures and sales for the past season. The questionnaires also captured socio-economic and institution data such as household characteristics, land size and tenure arrangements, farm characteristics and investment in assets. Other questions related to farmers' management capacity and demographic characteristics such as the supply of on-farm family labour and education status.

The farmers' risk attitude was elicited using the experimental gambling approach as outlined by [31]. Here, the study farmers were presented with a series of choices among sets of alternative prospects (gambles) that do not involve real money payments. Respondents were required to make a simple choice among eight gambles whose outcomes were determined by a flip of a coin. The experimental approach remedies some of the more serious measurement flaws of the direct elicitation utility (DEU) interview method reporting that evidence on risk aversion using direct elicitation utility through pure interviews is unreliable, nonreplicable and misleading even if one is interested only in a distribution of risk aversion rather than reliable individual measurements [31,32]. The farmers were further asked in the field survey to give their perceptions of the main sources of risk that affect their farming activity by ranking a set of 20 potential sources of risk on like rt-type scales ranging from 1 (no problem) to 3 (severe problem). These sources of risk were developed from findings of the research survey and from past research on the sources of risk in agriculture, challenges that smallholder farmers face in trying to access formal supply chains. The farmers were also requested to score any other sources of risk(s) that they wanted to add to the list of hypothesized sources of risk. These 
sources of risk are ranked from 1 (being the most important source of risk) to 20(being the least important source of risk ones). The ranking was done by averaging the scores on each source of risk and assigning a rank accordingly.

The study area in the Eastern Cape was stratified into the OR Tambo District Municipality and the Amatole District Municipality representing a broad spectrum of consumers across the Province. The stratified study areas were further clustered into rural, peri-urban and urban areas. The respondents were selected by simple random sampling to avoid bias. A total of 100 consumers were selected from OR Tambo District Municipality and represented by a selection of 30 respondents from peri-urban location, 40 respondents from urban suburbs and 30 respondents from rural areas. In the Amatole District Municipality, 100 consumers selected and interviewed included 30 respondents from rural Cata, 40 urban respondents from the East London Suburbs and lastly 30 respondents drawn from the peri urban area of Kwezana and Tsathu villages. A structured questionnaire was used that covered the respondent's socioeconomic and demographic background, consumer knowledge and awareness of organic products, perceptions, attitudes as well as consumption decisions.

The ordered probit model was used to identify the determinants of farmers' decision to participate in organic farming. The dependent variable is the farmer's organic farming status and was placed in three ordered categories in the survey. The model is estimated as:

Organic farming status $=f\left(\begin{array}{l}\text { age, gender, education, household size, farm size, farm income, off farm income, input costs, } \\ \text { land tenure, location, land tenure, livestock, chicken ownership, risk attitudes and assets }\end{array}\right)$

The organic farming status is modelled using the ordered probit model with the model outcomes:

$\mathrm{S}_{\mathrm{i}}=3$ (fully-certified organic),

$\mathrm{S}_{\mathrm{i}}=2$ (partially-certified organic farming) and

$\mathrm{S}_{\mathrm{i}}=1$ (non-organic farmers).

The farmer's decision on their organic farming status is unobserved and is denoted by the latent variable $\mathrm{s}_{\mathrm{i}}{ }^{*}$. The latent equation below models how $\mathrm{s}_{\mathrm{i}}^{*}$ varies with personal characteristics and is represented as:

$$
s_{i}^{*}=X_{i}^{\prime} \alpha+\varepsilon_{i}
$$

Where:

- the latent variable $\mathbf{s}_{\mathbf{i}}{ }^{*}$ measures the difference in utility derived by individual $i$ from either being fully-certified organic, partially-certified organic or non-organic.

- $(i=1,2,3 \ldots \ldots \ldots \ldots \ldots n) \mathrm{n}$ represents the total number of respondents. Each individual $\mathrm{i}$ belongs to one of the three groups. 
- $X_{\mathrm{i}}$ is a vector of exogenous variables,

- $\alpha$ is a conformable parameter vector, and

- the error term $\varepsilon_{\mathbf{i}}$ is independent and identically distributed as standard normal, that is $\varepsilon_{\mathrm{i}} \sim N I D(0,1)$.

The observed variable $\left(\mathrm{S}_{\mathrm{i}}\right)$ relates to the latent variable $\left(\mathrm{s}_{\mathrm{i}}{ }^{*}\right)$ such that

$$
\begin{aligned}
& S_{i}=1 \text { if } s_{i}^{*} \leq 0 \\
& 2 \text { if } 0<s_{i}^{*}>\gamma \\
& 3 \text { if } s_{i}^{*}>\gamma
\end{aligned}
$$

Taking the value of 3 if the individual was fully-certified organic and 1 if the individual was non-organic. The implied probabilities are obtained as:

$$
\begin{aligned}
& \operatorname{Pr}\left\{S_{i}=1 \mid X_{i}\right\}=\operatorname{Pr}\left\{s_{i}^{*} \leq 0 \mid X_{i}\right\}=\Phi\left(-X_{i}^{\prime} \alpha\right) \\
& \operatorname{Pr}\left\{S_{i}=3 \mid X_{i}\right\}=\operatorname{Pr}\left\{s_{i}^{*}>\gamma \mid X_{i}\right\}=1-\Phi\left(\gamma-X_{i}^{\prime} \alpha\right) \\
& \text { and } \\
& \operatorname{Pr}\left\{S_{i}=2 \mid X_{i}\right\}=\Phi\left(\gamma-X_{i}^{\prime} \alpha\right)-\Phi\left(-X_{i}^{\prime} \alpha\right)
\end{aligned}
$$

Where $\gamma$ is the unknown parameter that is estimated jointly with $\alpha$. Estimation is based upon the maximum likelihood where the above probabilities enter the likelihood function. The interpretation of the $\alpha$ coefficients is in terms of the underlying latent variable model in equation 11.

The probability of the farmer being fully-certified organic can be written as

$$
\operatorname{Pr}\left(S_{i}=1\right)=\Phi\left(X_{i}^{\prime} \alpha_{1}\right)
$$

Where $\Phi($ ) is the cumulative distribution function (cdf) of the standard normal [33].

A measure of goodness of fit can be obtained by calculating

$$
\rho^{2}=1-\left[\ln L_{b} / \ln L_{o}\right]
$$

Where $\ln L_{\mathrm{b}}$ is the $\log$ likelihood at convergence and $\ln L_{\mathrm{o}}$ is the $\log$ likelihood computed at zero. This measure is bounded by zero and one. If all model coefficients are zero, then the measure is zero. Although $\mathrm{Q}^{2}$ cannot equal one, a value close to one indicates a very good fit. As the model fit improves, $\mathrm{Q}^{2}$ increases. However the $\varrho^{2}$ values between zero and one do not have a natural interpretation [34]. Another similar informal goodness of fit measure that corrects for the number of parameters estimated is 


$$
\rho^{2} \text { bar }=1-\left[\ln L_{b} K / \ln L_{o}\right] .
$$

Where $\mathrm{K}$ is the number of parameter estimates in the model (degrees of freedom)

For the experimental gambling approach, the utility function with Constant Partial Risk Aversion (CPRA) is used to get a unique measure of partial risk aversion coefficient for each game level. This depicted as the equation below:

$$
U=(1-S) c^{(1-S)}
$$

Where

$S=$ coefficient of risk aversion, and

$c=$ certainty equivalent of a prospect.

The Herfindahl Index (DHI) is used to calculate enterprise diversification and represent the specialization variable. Although, this index is mainly used in the marketing industry to analyze market concentration, it has also been used to represent crop diversification [35, 36]. Herfindhal index (DHI) is the sum of square of the proportion of individual activities in a portfolio. With an increase in diversification, the sum of square of the proportion of activities decreases, so also the indices. In this way, it is an inverse measure of diversification, since the Herfindhal index decreases with an increase in diversification. The Herfindhal index is bound by zero (complete diversification) to one (complete specialization).

$$
\text { Herfindhal index }(\mathrm{DHI})=\sum_{i=1}^{N} s_{i}^{2}
$$

Where

$N=$ number of enterprises and

$s_{i}=$ value share of each $i$-th farm enterprise in the farm's output. $s_{i}=x_{i} \mid \sum_{1} x_{i}$ is the proportion of the $i$-th activity in acreage / income.

\section{Results and discussions}

\subsection{Determinants of adoption of organic farming}

The summary statistics in Table 1 show that the average age of the farmers was over 50 years with younger people migrating to urban centres in search of better jobs. In the study area, most of the men are engaged in wage employment at the neighbouring sugarcane farms or as 
migrant workers in the cities of Durban, Johannesburg. Hence over $70 \%$ of the farmers were female. Education levels are low and are consistent with most rural farming communities in South Africa, where formal education opportunities are limited. Household sizes were large with family labour playing a major role in tilling the land. Small farm sizes averaging 0. 59 hectares for fully-certified organic farmers, 0.67 hectares for non-organic farmers and 0.71 hectares for partially-certified farming was common in KwaZulu-Natal.

The main sources of income were farm and off farm employment, the latter constituting wages or salary income and remittances. Farm income was highest for fully-certified organic farmers. This is an indication that the adoption of fully-certified organic farming and its commercialization has brought economic benefits to these otherwise poor rural households and is an important contributor to household income. The proportion of income from farming was highest among the fully certified organic farmers. While the average farmer was classified as risk averse, non-organic farmers were more risk averse than their organic counterparts. Riskaverse farmers are reluctant to invest in innovations of which they have little first-hand experience. Despite the tenure system being communal, farmers felt they had tenure rights through the permission to occupywith allocation done by the traditional chief of the tribe (inkosi) and his headman (induna). On average the farmers acknowledged that the household had rights to exercise on its own cropland the building of structures, planting trees and bequeathing to family members or leasing out. Fully certified farmers had more assets than their non-organic counterparts as well as chicken and livestock.

\begin{tabular}{|c|c|c|c|c|c|c|}
\hline \multirow[b]{2}{*}{ Variable } & \multicolumn{2}{|c|}{ Fully-certified organic } & \multicolumn{2}{|c|}{ Partially-certified organic } & \multicolumn{2}{|c|}{ Non-organic } \\
\hline & Mean & Std. Dev & Mean & Std. Dev & Mean & Std. Dev \\
\hline Age (years) & 52.60 & 1.90 & 48.60 & 1.41 & 52.70 & 2.11 \\
\hline Gender (1=female) & 0.82 & 0.05 & 0.71 & 0.05 & 0.84 & 0.05 \\
\hline Education (years) & 4.94 & 4.24 & 4.37 & 4.49 & 3.38 & 0.61 \\
\hline Household size & 9.49 & 5.23 & 7.72 & 3.68 & 6.60 & 3.46 \\
\hline Land size (hectares) & 0.59 & 1.22 & 0.71 & 1.16 & 0.67 & 1.43 \\
\hline Input costs (rand/year) & 812.90 & 884.90 & 309.30 & 343.40 & 318.20 & 302.90 \\
\hline Proportion of income from farming & 0.62 & 0.79 & 0.38 & 1.04 & 0.39 & 0.63 \\
\hline Farm income (rands/year) & 973.17 & 1074.51 & 417.26 & 271.50 & 400.53 & 429.53 \\
\hline Location & 2.56 & 0.60 & 1.91 & 0.54 & 4.00 & 0.00 \\
\hline Arrow Pratt Risk Aversion coefficient & 0.55 & 0.29 & 0.58 & 0.31 & 0.76 & 0.29 \\
\hline Land rights $(0=$ no $)$ & 1.98 & 0.14 & 1.75 & 0.56 & 1.93 & 0.33 \\
\hline Chicken ownership & 15.29 & 13.16 & 9.25 & 8.69 & 6.40 & 6.62 \\
\hline Asset ownership (index) & 0.98 & 0.60 & 0.56 & 0.59 & 0.67 & 0.75 \\
\hline
\end{tabular}

Table 1. Summary statistics of sampled farmers in KwaZulu-Natal $(n=200)$ 
The ordered probit model results are presented in Table 2. The model successfully estimated the significant variables associated with the farmer's adoption decisions. The Huber/White/ sandwich variances estimator was used to correct for heteroscedasticity. The explanatory variables collectively influence the farmer's decision to be a certified organic with the chisquare value significant at one percent. The following variables were found to be significant determinants in the organic farming adoption decision by smallholder farmers in the study area: age, household size, land size, locational setting of the farmer depicted by the sub-wards Ogagwini, Ezigani, and Hwayi, farmer's risk attitude, livestock ownership (chicken and goat ownership), land tenure security as depicted by the rights the farmer can exercise on his/her own cropland to build structures and asset ownership.

\begin{tabular}{|c|c|c|c|}
\hline Variables & Parameter & Robust std error & P-values \\
\hline Age & 0.0194072 & 0.0079204 & $0.014^{\star * *}$ \\
\hline Gender & 0.3796234 & 0.2707705 & 0.161 \\
\hline Household size & 0.0504668 & 0.0271520 & $0.063^{*}$ \\
\hline Land size & -0.2352607 & 0.1083583 & $0.030 * \star$ \\
\hline Off Farm Income & -0.0001223 & 0.0001129 & 0.279 \\
\hline \multicolumn{4}{|l|}{ Location (sub-ward) } \\
\hline Location (1= ogagwini) & 2.894311 & 0.6380815 & $0.000 * * *$ \\
\hline Location (1=ezigani) & 4.191274 & 0.7234394 & $0.000 * * *$ \\
\hline Location (1=hwayi) & 5.158803 & 0.8495047 & $0.000 * * *$ \\
\hline Risk attitudes & -0.759508 & 0.3773067 & $0.044^{* *}$ \\
\hline \multicolumn{4}{|l|}{ Fertility (Manure) } \\
\hline Chicken ownership & 0.0424046 & 0.0148472 & $0.004^{* * *}$ \\
\hline Cattle ownership & -0.0418692 & 0.0431078 & 0.331 \\
\hline Goat ownership & -0.1005212 & 0.0569375 & $0.077^{\star}$ \\
\hline \multicolumn{4}{|l|}{ Land tenure rights } \\
\hline Land tenure ( $1=$ build structures) & 0.4803418 & 0.2372247 & $0.043^{* *}$ \\
\hline Land tenure ( $1=$ plant trees) & 0.0235946 & 0.3023182 & 0.938 \\
\hline Land tenure ( 1 = bequeath) & 0.1335225 & 0.2619669 & 0.610 \\
\hline Land tenure ( $1=$ lease out $)$ & -0.3840883 & 0.2593139 & 0.139 \\
\hline Land tenure ( $1=$ sell land) & 0.0829177 & 0.2978485 & 0.781 \\
\hline Asset ownership & 0.5853967 & 0.205389 & $0.004^{* \star *}$ \\
\hline
\end{tabular}

Significance levels: ${ }^{* *} p<0.01:{ }^{*} p<0.05:{ }^{*} p<0.1$

(Source: Field Data)

Table 2. Adoption of organic farming among smallholder farmers: Ordered probit model results 
The study established that older female farmers with large household sizes were more likely to be certified-organic. Similarly, farmers who reside in the sub-wards Ogagwini, Ezigani, and Hwayi were more likely to be certified organic. This suggests the presence of local synergies in adoption which raises the question about the extent to which ignoring these influences biases policy conclusions. The negative correlation between land size and adoption implies that smaller farms appear to have greater propensity for adoption of certified organic farming. This finding is supported by several studies reviewed in the literature that allude to the fact that organic farms tend to be smaller than conventional farms. The significance of livestock is explained by the importance of manure for organic farming. The study also found that older farmers tend to be adopters supporting findings by [37]. The propensity to adopt was also positively influenced by asset index which is a proxy for wealth.

\subsection{Risk aversion and risk management strategies}

The distribution of risk aversion preferences for each prospect for the fully-certified organic, partially-certified organic and non-organic crop farmers are presented in Table 3. The distribution of responses was spread across all classes of risk aversion for the pooled data. It can be noted that on average, the majority of the respondents revealed their preference for prospects representing intermediate and moderate risk aversion alternatives across the three farmer groups. Table 3 further shows that non-organic farmers were the most risk averse being classified as extremely risk averse at $20.4 \%$, compared to fully and partially-certified organic farmers at $7.3 \%$ and $4.2 \%$, respectively. This explains their non-adoption of certified organic farming, despite its introduction in the area since the year 2000. On the other hand, the fullycertified organic farmers were the least risk averse, being classified as neutral to risk preferring at $9.1 \%$ compared to $7.3 \%$ and $4.1 \%$ for the partially certified and non-organic farmers respectively. These results conform to a priori expectations regarding the risk preference patterns of smallholder farmers.

\begin{tabular}{lllllll}
\hline & \multicolumn{7}{c}{ Risk aversion classification } \\
\cline { 2 - 7 } Farmer group & Extreme & Severe & Intermediate & Moderate & $\begin{array}{l}\text { Slight to } \\
\text { neutral }\end{array}$ & $\begin{array}{l}\text { Neutral to } \\
\text { preferring }\end{array}$ \\
\hline Fully certified organic $(n=48)$ & 7.30 & 5.50 & 30.90 & 40.00 & 7.30 & 9.10 \\
Partially certified organic $(n=95)$ & 4.20 & 8.30 & 44.80 & 29.20 & 5.20 & 7.30 \\
Non-organic $(n=46)$ & 20.40 & 8.20 & 30.60 & 30.60 & 0.00 & 4.10 \\
\hline Pooled data $(n=189)$ & 9.00 & 7.50 & 37.50 & 32.50 & 4.50 & 7.00 \\
\hline
\end{tabular}

Source: Field data

Table 3. Distribution of smallholder farmers according to risk preference patterns in KwaZulu-Natal

According to Figure 4, the non-organic farmers constituted 55. 6\% of respondents within the extreme risk aversion class compared to $22.2 \%$ for fully-certified organic and $22.2 \%$ for 
partially-certified organic farmers. This is a confirmation of previous findings in this study that explains the non-adoption of certified organic farming by the non-organic farmers. In the risk neutral to preferring category, the non-organic farmers constitute only 14. 3\%. Fullycertified organic farmers constituted $57.1 \%$ and partially-certified organic farmers constituted $28.6 \%$.

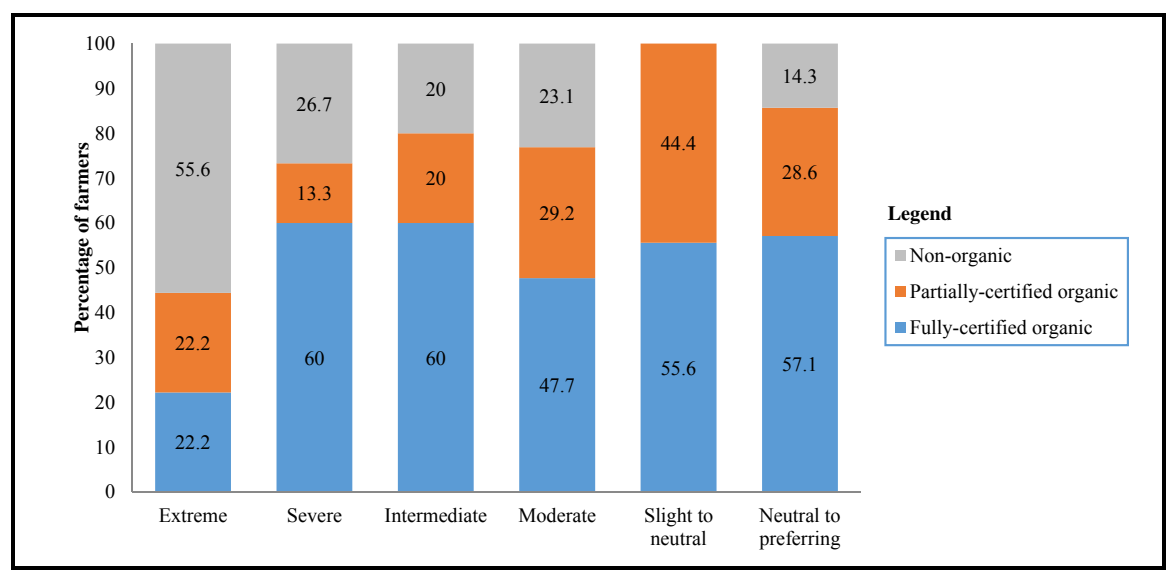

Figure 4. Frequency distribution within risk aversion classes across the farmer groups

A comparison of the results from the South African study, which applied the general experimental method, with similar studies using the same methodology was for farming communities in the Côte d'Ivoire [38], Ethiopia [39], Zambia [40], Philippines [41] and India [31], shows similarities in the findings of the studies done in India, Philippines, Zambia and Côte d'Ivoire, where the majority of the respondents are classified as intermediate to moderate risk aversion (Table 4). Similarly, these results suggest that farm households in South Africa are less risk averse than in Ethiopia, Zambia and Côte d'Ivoire but are much more risk averse than in India and Philippines.

Farmers identified their sources of risk and significance in terms of the potential impact to their farming activity as presented in Table 5. The fully-certified organic farmers cited in order of priority, uncertain climate (mean 2. 96), lack of cash and credit to finance inputs (mean 2. 78) and tractor unavailability when needed (mean 2. 76). These risk sources have a direct bearing on production of organic produce. Climatic conditions are beyond the farmers' control, and the top ranking probably reflects the farmers' concerns about the effects of recent drought in the Umbumbulu district. These impacts negatively on crop yield. Due to communal land ownership and strict conditions for credit, farmers have limited options to obtain production credit from financial institutions. Among the sampled farmers only 21 farmers were able to access credit. Farmers in the study area lack collateral that is acceptable to banks. For example, banks required title deeds as proof of land ownership but the majority of black farmers in 


\begin{tabular}{|c|c|c|c|c|}
\hline Studies & $\begin{array}{l}\text { Extreme to severe risk } \\
\text { aversion }\end{array}$ & $\begin{array}{l}\text { Intermediate to } \\
\text { moderate risk aversion }\end{array}$ & $\begin{array}{l}\text { Risk-neutral to risk } \\
\text { preferring }\end{array}$ & $\begin{array}{l}\text { Number of } \\
\text { responses }\end{array}$ \\
\hline \multicolumn{5}{|l|}{ India [31] } \\
\hline 50 rupee & 8.4 & 82.2 & 9.4 & 107 \\
\hline 500 rupee & 16.5 & 82.6 & 0.9 & 115 \\
\hline \multicolumn{5}{|c|}{ Philippines [41] } \\
\hline 50peso & 10.2 & 73.5 & 16.3 & 49 \\
\hline 500peso & 8.1 & 77.6 & 14.3 & 49 \\
\hline \multicolumn{5}{|c|}{ Zambia [40] } \\
\hline $1000 \mathrm{kw}$ & 29.1 & 46.4 & 24.5 & 423 \\
\hline $10000 \mathrm{kw}$ & 36.7 & 52.5 & 11 & 137 \\
\hline \multicolumn{5}{|c|}{ Ethiopia [39] } \\
\hline 5 bir & 45.4 & 33.6 & 21 & 262 \\
\hline 15bir & 55.7 & 27.5 & 16.8 & 262 \\
\hline \multicolumn{5}{|c|}{ Côte d'Ivoire [38] } \\
\hline 1000FCFA & 32.8 & 53.9 & 13.3 & 362 \\
\hline 5000FCFA & 46.1 & 45.9 & 8 & 362 \\
\hline \multicolumn{5}{|c|}{ *South Africa [42] } \\
\hline 400Rands & 16.5 & 70 & 11.5 & 196 \\
\hline
\end{tabular}

Table 4. Percentage distribution of revealed risk preferences in five experimental studies

South Africa and especially in the former homelands still lacked this vital documentation. Tractor unavailability can be attributed to the fact that there is one tractor that has been allocated to the members of Ezemvelo Farmers Organisation. The tractor is leased out at a rental fees. This poses a challenge during the land preparation phase when the demand for its services is at peak.

Similarly, partially-certified farmers also ranked tractor not being available when needed (mean 2. 89) and uncertain climate (mean 2. 83) as identified sources of risk (Table 5). The risk of delays in payment for products sent to pack house (mean 2. 89) are attributed to various factors, among them the contractual obligation the agent has with the retailer which has a bearing on the duration of payment. Payment is only made to the farmer once the supply has been forwarded to the retailer and there is confirmation of the quantity of produce that has been rejected. The process flow delays payments to farmers. Non-organic farmers also cited uncertain climate (mean 2. 82), livestock damage to crops (mean 2. 80) and lack of cash and credit to finance farm inputs (mean 2. 78). The livestock damage is a result of lack of fencing around the crops planted. 


\begin{tabular}{|c|c|c|c|c|c|c|c|c|c|}
\hline \multirow{3}{*}{$\frac{\text { Constraint }}{\text { Livestock damage }}$} & \multicolumn{3}{|c|}{ Fully-certified organic } & \multicolumn{3}{|c|}{ Partially-certified organic } & \multicolumn{3}{|c|}{ Non-organic } \\
\hline & \multirow{2}{*}{$\frac{\text { Mean }}{2.56}$} & \multicolumn{2}{|c|}{ Std.Dev. Rank } & \multirow{2}{*}{$\frac{\text { Mean }}{2.82}$} & \multicolumn{2}{|c|}{ Std.Dev. Rank } & \multirow{2}{*}{$\frac{\text { Mean }}{2.8}$} & \multicolumn{2}{|c|}{ Std.Dev. Rank } \\
\hline & & 0.774 & 7 & & 0.448 & 4 & & 0.539 & 2 \\
\hline Uncertain climate & 2.96 & 0.189 & 1 & 2.83 & 0.409 & 3 & 2.82 & 0.486 & 1 \\
\hline \multicolumn{10}{|l|}{ Uncertain prices for products sold to pack } \\
\hline house & 2.21 & 0.793 & 13 & 2.13 & 0.591 & 16 & - & - & - \\
\hline \multicolumn{10}{|l|}{ Uncertain prices for products sold to other } \\
\hline markets & 1.94 & 0.811 & 17 & 2.02 & 0.595 & 18 & 2.17 & 0.761 & 10 \\
\hline Huge work load & 2.58 & 0.599 & 6 & 2.32 & 0.688 & 12 & 2.53 & 0.649 & 4 \\
\hline Lack of cash and credit to finance inputs & 2.78 & 0.567 & 2 & 2.58 & 0.615 & 6 & 2.78 & 0.468 & 3 \\
\hline \multicolumn{10}{|l|}{ Lack of information about producing } \\
\hline organic crops & 2.02 & 0.687 & 15 & 2.2 & 0.632 & 14 & 2.16 & 0.717 & 11 \\
\hline \multicolumn{10}{|l|}{ Lack of information about alternative } \\
\hline markets & 2.38 & 0.623 & 10 & 2.29 & 0.602 & 13 & - & - & - \\
\hline Lack of proper storage facilities & 2.56 & 0.66 & 7 & 2.46 & 0.543 & 9 & 2.41 & 0.643 & 7 \\
\hline Lack of affordable transport for products & 2.72 & 0.492 & 4 & 2.42 & 0.56 & 11 & 2.06 & 0.852 & 12 \\
\hline Lack of telephone to negotiate sales & 2.69 & 0.509 & 5 & 2.55 & 0.633 & 8 & 2.22 & 0.771 & 8 \\
\hline Inputs not available at affordable prices & 2.52 & 0.642 & 9 & 2.8 & 0.447 & 5 & 2.51 & 0.545 & 5 \\
\hline Tractor not available when needed & 2.76 & 0.501 & 3 & 2.89 & 0.416 & 1 & 2.46 & 0.713 & 6 \\
\hline Cannot find manure for purchase & 1.92 & 0.778 & 18 & 2.56 & 0.66 & 7 & 2.2 & 0.645 & 8 \\
\hline Cannot find labour to hire & 1.73 & 0.764 & 20 & 1.76 & 0.816 & 20 & 2 & 0.764 & 13 \\
\hline Cannot access more cop land & 1.95 & 0.753 & 16 & 1.98 & 0.805 & 19 & 1.92 & 0.794 & 14 \\
\hline \multicolumn{10}{|l|}{ Delay of payment of products sent to pack } \\
\hline house & 2.22 & 0.723 & 12 & 2.89 & 0.315 & 1 & - & - & - \\
\hline \multicolumn{10}{|l|}{ Lack of bargaining power over product } \\
\hline prices at the pack house & 2.16 & 0.672 & 14 & 2.2 & 0.704 & 14 & - & - & - \\
\hline \multicolumn{10}{|l|}{ Lack of information about consumer } \\
\hline preferences for organic products & 2.23 & 0.654 & 11 & 2.44 & 0.604 & 10 & - & - & - \\
\hline \multicolumn{10}{|l|}{ No reward system or incentive for } \\
\hline smallholder producers & 1.86 & 0.78 & 19 & 2.02 & 0.866 & 17 & - & - & - \\
\hline
\end{tabular}

Table 5. Identification and ranking of risk sources by farmers

The most important traditional risk management strategies used by the farmers were identified as crop diversification, precautionary savings and participating in social network. The overall Herfindahl index of crop diversification is estimated at 0.61 which indicates that the cropping system is relatively diverse (Table 6). These results confirm previous findings by [43] who 
obtained an estimated DHI of 0. 49-0. 69 among smallholder farmers in three regions in Bangladesh. As shown in Table 6, non-organic farmers practiced more crop diversification with a DH index of 0.23 compared to organic farmers with a DHI of 0.72 . These results are consistent with previous findings in this study measuring farmers risk attitudes and presented in Figure 6. 8, that established that smallholder farmers in the study area tend to diversify due to their risk averse nature and that non-organic farmers are more risk averse than organic farmers.

According to Table 6, a total of $69.1 \%$ of fully-certified farmers practised crop diversification compared to $96.8 \%$ of the non-organic farmers. A total of $81.2 \%$ of the partially certified farmers practised crop diversification. The common crops grown by the organic farmers are amadumbe, potatoes, sweet potatoes and green beans while non-organic farmers grew amadumbe, potatoes, sweet potatoes, green beans, maize, sugarcane, bananas, chillies and peas.

\begin{tabular}{|c|c|c|c|c|}
\hline No. & Risk management strategy & $\begin{array}{l}\text { Fully-certified } \\
\text { organic }\end{array}$ & $\begin{array}{l}\text { Partially-certified } \\
\text { organic }\end{array}$ & Non-organic \\
\hline & & $n=48$ & $n=103$ & $n=49$ \\
\hline 1 & Enterprise diversification index (DH) & 0.72 & 0.89 & 0.23 \\
\hline \multirow[t]{2}{*}{2} & Practice crop diversification (\% of & & & \\
\hline & respondents) & 69.10 & 81.20 & 96.80 \\
\hline 3 & Savings bank account (\% of respondents) & 60.90 & 48.90 & 46.80 \\
\hline \multirow[t]{5}{*}{4} & Current level of savings ( $\%$ of respondents) & & & \\
\hline & less than R500 & 27.27 & 37.84 & 35.29 \\
\hline & R501 - R1000 & 45.45 & 29.73 & 41.18 \\
\hline & $\mathrm{R} 1001-\mathrm{R} 5000$ & 21.21 & 29.73 & 17.65 \\
\hline & More than 5000 & 6.07 & 2.70 & 5.88 \\
\hline \multirow[t]{3}{*}{5} & Social networks (\% of respondents) & & & \\
\hline & Membership of EFO & 100.00 & 100.00 & 10.00 \\
\hline & Others (burial clubs,stockvels) & 33.00 & 25.00 & 25.00 \\
\hline
\end{tabular}

Table 6. Risk management strategies used by the different farmer groups

Precautionary saving occurs in response to risk and uncertainty [44]. The smallholder farmers' precautionary motive was to delay/minimise consumption and save in the current period due to their lack of crop insurance markets. According to [45], the quantitative significance of precautionary saving depends on how much risk consumers face. Whereas $60.9 \%$ of the fully certified farmers had savings bank accounts, only $46.8 \%$ non-organic farmers had bank accounts. The current level of saving in the study area was low with savings ranging from less than R500 to over R5000 per month. The level of savings was low across all groups. Among 
the fully-certified organic group, most of the respondents (45. 45\%) saved between R1000R5001 whereas most of the partially-certified farmers (37.84\%) saved less than R500 per month. Most of the non-organic farmers (41. 18\%) saved between R501-R1000 per month. Across all groups, however the level of saving greater than R5000 was minimal.

The farmers also engage in social networks as a risk sharing strategy. There were two main categories of social networks that the farmers engaged in. These are farmers association and other social networks most notably burial clubs and stockvels. The farmers association is used as a vehicle by the organic farmers to gain access to markets for their organic produce while the burial clubs and stockvels are sources of access to credit and/or loans. In the latter instance, farmers do not have to produce collateral. The burial clubs and stockvels are common in most rural areas and are a source of mitigating liquidity and financial risk where possible.

\subsection{Consumer awareness, perceptions and consumption decisions}

The summary statistics of consumers presented in Table 7 showed that the majority of the consumers were females within 25-34 age category. Previous studies for example [46] found that women were the predominant purchasers of organic food and responsible for household consumption. The younger generation consumers represent an important target group in the advancement of consumer demand for organic products. The level of education was generally low especially among rural consumers. The unemployment rates in the former homelands demonstrates a substantial skewering of the demographic profile of the district and high dependency rates of those not economically and productively active. It also reflects the levels of out migration of economically active population from the province to other parts of South Africa. Unemployment was also lower in urban areas than rural areas. The income distribution of the respondents is especially concentrated in the R1000 - R5000/month category. However the majority of the respondents within this category were in the rural areas. This can be attributed to limited economic activity in rural areas. The household size was within the provincial estimate of 4-5 persons per household [47] with rural households having higher numbers. Majority of the respondents had children under the age of 18 years in the household. The average distance to the nearest shops were estimated at between $6-9 \mathrm{kms}$. In the urban areas however this was reduced to $1.38 \mathrm{kms}$.

There is a general understanding of term 'organic foods' among consumers. Consumers defined organic foods as healthy and nutritious, associated with traditional and or indigenous methods of production and free from chemicals. There were low levels of awareness about local standards for organic products, the identification of organic products using an organic logo, existence of a national organic movement and/or the presence of an organic certification body in South Africa. Therefore consumers could not readily identify certified organic against non-certified organic products. Notwithstanding, consumers argued that there was a need for certification and verification of organic products and hence are unable to make informed decisions on the organic status of products in the market.

Trust of organic labels can be increased once more information is available to consumers on the various organic labels, their meaning and on the difference between certified and non 


\begin{tabular}{|c|c|c|c|c|c|c|}
\hline & & \multicolumn{2}{|c|}{ Former Homelands } & \multicolumn{3}{|c|}{ Locality } \\
\hline & & OR Tambo DM & Amatole DM & Rural & Peri-urban & Urban \\
\hline Variable & & $n=100$ & $n=100$ & $\mathrm{n}=30$ & $\mathrm{n}=\mathbf{3 0}$ & $n=40$ \\
\hline \multirow[t]{2}{*}{ Gender } & Male & 43 & 34 & 28 & 40 & 44 \\
\hline & Female & 57 & 66 & 72 & 60 & 56 \\
\hline \multirow[t]{5}{*}{ Age in years } & $18-24$ & 17 & 13 & 18 & 16 & 12 \\
\hline & $25-34$ & 29 & 33 & 12 & 34 & 26 \\
\hline & $35-44$ & 27 & 16 & 14 & 23 & 41 \\
\hline & $45-55$ & 20 & 17 & 21 & 19 & 16 \\
\hline & $>55$ & 7 & 21 & 35 & 8 & 5 \\
\hline \multirow[t]{4}{*}{ Education Level } & None & 4 & 9.7 & 16.1 & 6.5 & 1.2 \\
\hline & Primary & 21 & 29.1 & 46.4 & 32.3 & 5.9 \\
\hline & High school & 39 & 39.8 & 37.5 & 48.4 & 34.1 \\
\hline & Tertiary & 36 & 21.4 & 0 & 12.9 & 58.8 \\
\hline \multirow[t]{6}{*}{ Employment Status } & Unemployed & 29.4 & 31 & 52.6 & 48.3 & 2.4 \\
\hline & Student & 9.8 & 4 & 5.3 & 5 & 9.4 \\
\hline & Housewife/man & 10.8 & 8 & 19.3 & 10 & 2.4 \\
\hline & Retired & 5.9 & 1 & 8.8 & 1.7 & 1.2 \\
\hline & Working part-time & 14.7 & 11 & 8.7 & 18.3 & 11.8 \\
\hline & Working full time & 29.4 & 45 & 5.3 & 16.7 & 72.8 \\
\hline \multirow[t]{5}{*}{ Income Level } & $<1000$ & 10 & 12.5 & 0 & 4.8 & 23.5 \\
\hline & $1001-5000$ & 16 & 5.8 & 0 & 0 & 25.9 \\
\hline & $5001-10000$ & 20 & 17.3 & 5.3 & 17.7 & 28.2 \\
\hline & $10001-15000$ & 30 & 49 & 66.7 & 46.8 & 16.5 \\
\hline & $>15000$ & 24 & 15.4 & 28.1 & 30.6 & 5.9 \\
\hline \multicolumn{2}{|c|}{ Household size in number } & 5.2 & 4.33 & 5.18 & 4.98 & 4.31 \\
\hline \multicolumn{2}{|l|}{ Children $<18$ years } & 79 & 55.8 & 71.9 & 71 & 61.2 \\
\hline \multicolumn{2}{|l|}{ Distance in Kms } & 6.71 & 9.63 & 12.67 & 9.32 & 1.38 \\
\hline
\end{tabular}

Table 7. Summary statistics of consumers in the Eastern Cape Province

certified products in the shelves. In the absence of this information, producers and likewise consumers may not get value for money. Certification and labelling is essentially in regulating and facilitating the sale of organic products to consumers. The perception of the high price of organic products is a deterrent to the purchase of organic products and hence the growth of organic industry especially for the emerging organic market of South Africa. To increase the consumption of organic products, it will be important to motivate new consumer segments to buy organic food. Hence trust is a crucial aspect when consumers decide whether to buy or not to buy organic products [48]. 
Trust is a 'credence attribute' which is not directly observable by consumers. Enhancing consumers trust about the labels of organic products can be achieved through among others, effective communication strategies on the traceability of organic products and ensuring compliance and adherence by retailers selling organic products to the certification standards and availability of information on the organic status of products. Some of the reasons advanced in the study to increase consumers trust for organic products is to:

- purchase from specific shops that sell organic

- check for organic certification label

- practice own organic farming

In South Africa, food retailers have the largest share of the organic industry [49]. Similarly, most products are sold through the export market due to the higher revenue from exports. Irwin [50] says that South Africa has a favourable position for expansion in the domestic market as a result of the following developments in the organic sector over the past few years:

- establishment of separate organic section in major retail stores

- national regulation/standards for organic products

- establishment of South Africa organic certification bodies

- formation of South African organic associations.

Food purchasing is an important part of food behaviours. In this study the apportioning, explicitly or tacitly, of the responsibility of household food shopping depends on a number of factors as food purchasing is an important part of food behaviours. This responsibility was closely shared among various members of the household with majority of the consumers being responsible for the decision making of organic food demand and purchase. The general finding in the study was that most consumers shop in supermarkets, grocery stores and spaza ( $k i$ osks) shops. The majority of consumers who shop in supermarkets reported that local shops do not provide the services people demand and that food choice and quality are limited. This is coupled with discount promotions common with supermarkets and variety of products. The findings from this study are consistent with findings from the Food Safety Agency [51] that state that a vast majority (92\%) of consumers continue to use supermarkets for most of their food shopping. However, local shops play an important role in 'top-up' shopping, being used by $75 \%$ consumers for some of their food purchases.

Commonly consumed organic products included fresh vegetables, fresh fruits, meat/meat products and milk/ milk products. However, the general trend in Figure 5 and Figure 6 shows that there are marked increases in the future demand of all organic products. This augurs well for the growth of the organic industry in the Eastern Cape and in South Africa in General. The findings of this study are consistent with [52] who stated that a study by Pick-n-Pay, one of the major national retail supermarket chains and supporter of the development of the retail organic market in South Africa, on the performance and trends of fresh organic produce showed that fresh produce completely dominated the sales. 


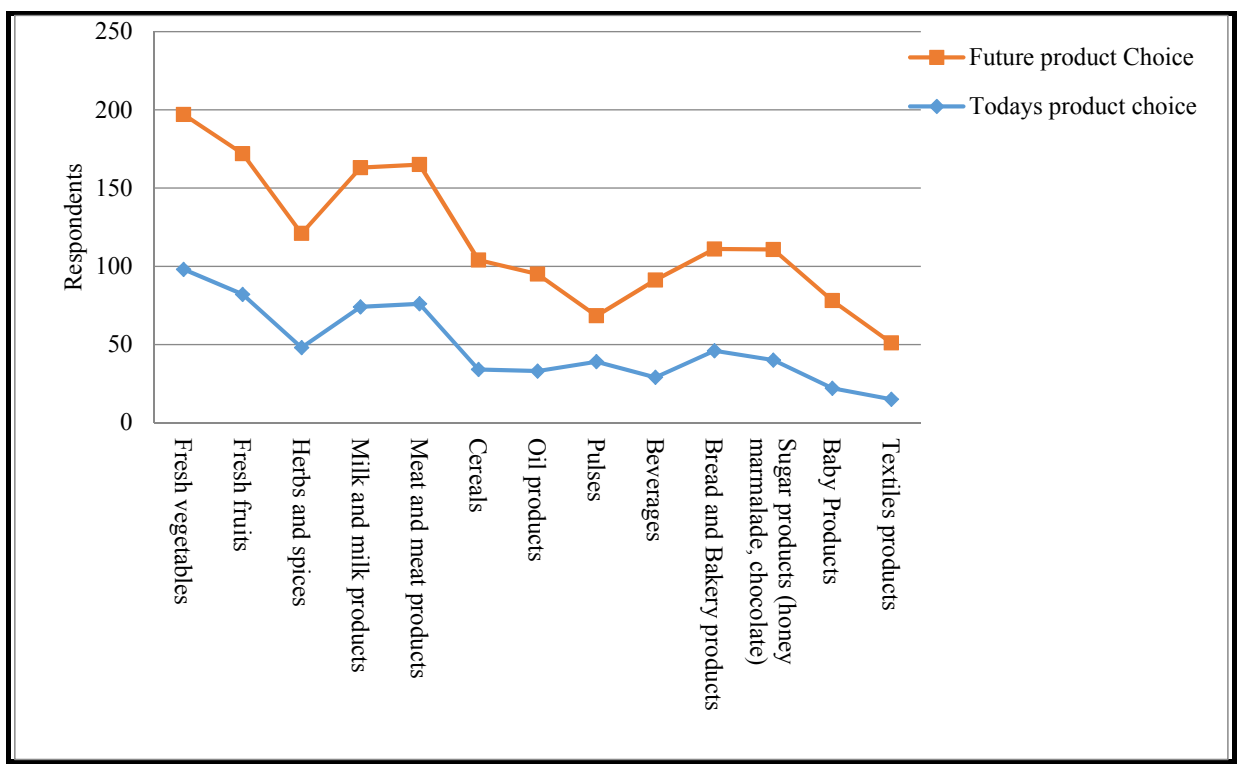

Figure 5. Demand difference between organic products today and in the future in OR Tambo District Municipality

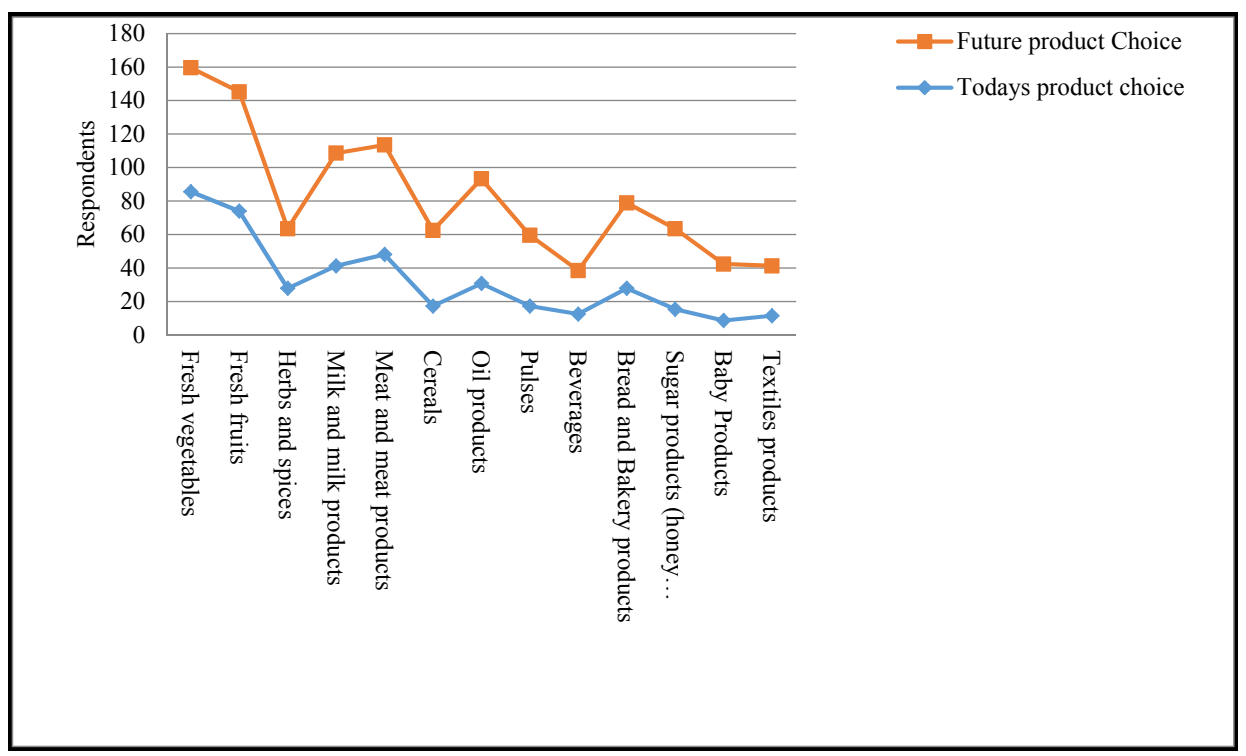

Figure 6. Demand difference between organic products today and in the future in Amatole District Municipality 
This is an indication that the consumption of organic products is closely related to consumer awareness and knowledge of organic products. Increasing awareness about organic products to consumers is important to spur its demand. Most of the consumers had consumed organic products in South Africa with non consumers showing a general interest in organic products. Authors [53] state that consumer awareness of organic foods is the first step in developing demand for organic products. Yet, awareness does not necessarily equate with consumption. While organic refers to the way agricultural products are grown and processed [54], interest in consuming organic products may relate to food safety concerns where organic products may be a partial answer to recent food scares associated with production and handling (e. g. BSE, dioxins, Salmonella, etc. ). Food safety issues have driven consumers to search for safer foods whose qualities and attributes are guaranteed [55]. The main reasons advanced for the consumption of organic products are that organics are healthy and nutritious, have a better appearance and taste, are affordable and are safe to consume. Identified hindrances to the consumption of organics are that they are expensive and not readily available. Price and affordability of organic products was ranked as the most important consideration among all consumers when buying organic products in South Africa.

\section{Conclusions}

The global markets for organic products have grown rapidly over the past two decades [8]. Currently 32. 2 million ha are being managed organically worldwide by more than 1.2 million producers [11]. In Africa, South Africa has the third largest area (50, 000ha) under organic farming [11]. Organic production is particularly well-suited for smallholder farmers, who comprise the majority of the world's poor. The promotion of organic agriculture does not only constitute an important option for producersbut also responds to consumers' desire for higher food quality and food production methods that are less damaging to the environment. The consumers' concerns for food safety, quality and nutrition are increasingly becoming important across the world, which has provided growing opportunities for organic foods in recent years. Expectedly, the demand for organic food is steadily increasing in the developing countries. The untapped potential markets for organic foods in the countries like South Africa need to be realised with organised interventions on various fronts, which require a better understanding of the consumers' preference for organic food. Therefore, an analysis of consumer's awareness of various aspects of organic products may be considered as important ground to build the markets for organic food in the initial phase of market development. Recent analysis [53] indicate that consumer awareness of organic foods is the first step in developing demand for organic products. By identifying independent variables that explain the adoption of organic farming, the present study sought to contribute to policy formulation to promote adoption in South Africa and the rest of Africa. The identified sources of risk faced by smallholder farmers provide useful insights for policy makers, advisers, developers and sellers of risk management strategies. This information can yield substantial payouts in terms of the development of quality farm management and education programs as well as the design of more effective government policies. 


\section{Author details}

Maggie Kisaka-Lwayo and Ajuruchukwu Obi

*Address all correspondence to: aobi@ufh.ac.za

Department of Agricultural Economics \& Extension, University of Fort Hare, Alice, South Africa

\section{References}

[1] Tilman D, Cassman KG, Matson PA, Naylor R, Polasky S. Agricultural Sustainability and Intensive Production Practices. Nature 2002; (418)671-677.

[2] Food and Agricultural organization. FAO. Assessment of the World Food Security Situation, Report CFS2007/2. Rome; 2007.

[3] Willer H, Rohwedder M. , Wynen E. Organic Agriculture Worldwide: Current Statistics. In Willer H. , Kilcher L. (ed. ): The World of Organic Agriculture. Statistics and Emerging Trends 2009. ITC Geneva; 2009.

[4] Oelofse M, Høgh-Jensen H, de Abreu LS, de Almeida GF, Sultan T, Yu Hui Q, deNeergaard A. Certified Organic Agriculture in China and Brazil: Market Accessibility and Outcomes Following Adoption. Ecological Economics 2010; (69) 1785-1793.

[5] Byerlee D. , Alex G. Organic farming: a contribution to sustainable poverty alleviation in developing countries? Forum for Environment and Development, Bonn. Report; 2005.

[6] UNEP-UNCTAD. Sector Background Note - Organic Agriculture. http: //www. unep-unctad. org/cbtf/events/geneva5/Word Backgroundnoteorganic agriculture_ 01102007. pdf (accessed 15 June 2010).

[7] UNCTAD. Organic Agriculture: A Trade and Sustainable Development Opportunity for Developing Countries. In UNCTAD/ DITC/TED/2005/12. (ed. )UNCTAD Trade and Environment Review 2006. United Nations New York and Geneva; 2006.

[8] Sahota A. The Global Market for Organic Food and Drink. In Willer H. , Kilcher L. (Eds. ) The World of Organic Agriculture. Statistics and Emerging Trends 2011. IFOAM Bonn and FiBL Frick; 2011.

[9] Willer H. , Yussefi M. The World of Organic Agriculture 2005. Statistics and Emerging Trends. IFOAM Publication, Tholey-Theley, Germany; 2006 
[10] Parrott N, Ssekyewa C, Makunike C. , Ntambi S M. Organic Farming in Africa. In Willer/Yussefi (eds. ) The World of Organic Agriculture. Statistics and Emerging Trends 2006. IFOAM, Bonn; 2006.

[11] Willer H. , Klicher L. The World of Organic Agriculture. Statistics and Emerging Trends 2009. IFOAM, Bonn, Germany and Research Institute of Organic Agriculture, FIBL, Frick, Switzerland; 2009.

[12] Walaga C. Organic Agriculture in the Continents. In Yusseffi M. , Willer H. (ed. ) The World of Organic Agriculture: Statistics and Future Prospects; 2003.

[13] Ssekyewa C. Organic agriculture research in Uganda. Paper presented at the International Society for Organic Agriculture Research (ISOFAR) Scientific Conference, 20th-23rd September 2005, Adelaide, Australia; 2005

[14] FiBL/IFOAM: Key Results from Survey on Organic Agriculture Worldwide. www. fibl. org (accessed 9 September 2009).

[15] Moffet J. Principles of organic farming. Paper contributed at the 1st short course in organic farming, 25th-27th October, Spier Institute and Ellensburg Agricultural College; 2001

[16] GROLINK. Feasibility study for the establishment of certification bodies for organic agriculture in Eastern and Southern Africa, Report commissioned by Sida/INEC, Höje; 2002

[17] International Trade Centre. ITC. Organic Food and Beverages: World Supply and Major European Markets. www. intracen. org/mds/sectors/organic/welcome. htm (accessed 10 January 2010).

[18] ScialabbaN. E. , Hattam C. Organic Agriculture, Environment and Food Security. http: //www. fao. org/docrep/005/y4137e/ y4137e00. HTM (accessed 2 July 2011).

[19] Arnold G. The Resources of the Third World. Cassell, London; 1997.

[20] Millstone E. , Lang T. The Atlas of Food: Who Eats What, Where and Why?Earth Scan, London; 2002

[21] Mahlanza B, Mendes E, Vink N. Comparative Advantage of Organic Wheat Production in the Western Cape. Agrekon 2003; (42) 144-162.

[22] Troskie D P. Factors influencing organic production: An economic perspective. Paper presented at 12 Annual Interdisciplinary Symposium, 12 September, ARC-PPRI, Stellenbosch; 2001

[23] International Federation of Organic Agriculture Movements. IFOAM. IFOAM's Position on Smallholder Group Certification for Organic Production and Processing. http: //www. ifoam. org/press/positions/Small_holder_group_certification. html(accessed 17 April 2011). 
[24] Naegeli F, Torrico JC. The Potential of Organic Agriculture to Improve Food Security. CienciAgro 2009; (1) 144-151.

[25] Zundel C. , Kilcher L. Organic agriculture and food availability. Issues Paper, International Conference on Organic Agriculture and Food Security, 3-5 May, Rome; 2007

[26] Connor D J. Organic Agriculture Cannot Feed the World. Field Crops Research 2008 (106)187-190.

[27] Badgley C, Moghtader J, Quintero E, Zakem E, Chappell MJ, Avile's-Va'zquez K, Samulon A, Perfecto I. Organic Agriculture and the Global Food Supply. Renewable Agricultural Food Systems 2007 (22): 86-108.

[28] Statistics South Africa. STATSSA. Mid-year Population Estimates: Statistical Release P0302. http: //www. statssa. gov. za/ publications/P0302/P03022010. pdf(accessed 12 July 2011).

[29] OR Tambo District Municipality Integrated Development Plan. ORTIDP. OR Tambo District Municipality Integrated Development Plan. http: //www. ortambodm. org. za/files/PDF/pplan2012to2013. pdf (accessed 5 October 2011).

[30] Community Survey. CS. Statistical Release P0301. 1. Basic Results for Municipalities. http: //www. statssa. gov. za/publications/p 03011/p030112007. pdf (accessed 5 October 2011).

[31] Binswanger HP. Attitudes towards Risk: Experimental Measurement in Rural India. American Journal of Agricultural Economics 1980(62)395-407.

[32] Young DL. Risk Preferences of Agricultural Producers: Their Use in Extension and Research. American Journal ofAgricultural Economics 1979 (61) 1063-70.

[33] Verbeek M. A Guide to Modern Econometrics. John Wiley and Sons Ltd; 2008

[34] Greene W H. Econometric Analysis. $5^{\text {th }}$ ed. Prentice Hall, New Jersey; 2003

[35] Llewelyn RV, Williams JR. Nonparametric Analysis of Technical, Pure Technical and Scale Efficiencies for Food Crop Production in East Java, Indonesia. Agricultural Economics 1996 (15) 113-126.

[36] Bradshaw B. Questioning Crop Diversification as Response to Agricultural Deregulation in Saskatchewan, Canada. Journal of Rural Studies 2004 (20)35-48.

[37] Feng XHE. , Chenqi D. Adoption and diffusion of sustainable agricultural technology: an econometric analysis. Report. Chongqing Institute of TechnologyChina; 2010

[38] Kouamé EB H. Risk, risk aversion and choice of risk management strategies by cocoa farmers in Western Cote d'ivoire. University of Cocody-AERC Collaborative PhD Programme. Abidjan-Côte d'Ivoire; 2010

[39] Yesuf M. Risk aversion in low income countries: experimental evidence from Ethiopia. Discussion paper 715. IFPRI, Washington D. C; (2007). 
[40] Wik M, Holden ST. , Taylor E. Risk, market imperfections and peasant adaption: evidence from Northern Zambia. Discussion paperno. 28/1998, Department of Economics and Social Sciences, Agricultural University of Norway; 1998

[41] Sillers DA. Measuring risk preference of rice farmers in Nueva Ecija, Philippines: An experimental approach. PhD dissertation, Yale UniversityU. S. A.; 1980.

[42] Lwayo M. Risks preference and consumption decisions in organic production: The case of KwaZulu-Natal and Eastern Cape Provinces. PhD thesis, University of Fort Hare, South Africa; 2012

[43] Rahman S. Whether Crop Diversification is a Desired Strategy for Agricultural Growth in Bangladesh?Food Policy 2009 (34)340-349.

[44] Feigenbaum J. Precautionary Saving or Denied Dis-saving. Economic Modelling 2011 (28)1559-1572,

[45] Cunha F, Heckman J, Navarro S. Separating Uncertainty from Heterogeneity in Life Cycle Earnings. Oxford Economic Papers 2005(57) 191-261.

[46] Mutlu N. Consumer attitude and behaviour towards organic food: Cross-cultural study of Turkey and Germany. Master's thesis. University of Hohenheim Germany; 2007.

[47] PROVIDE. A profile of the Eastern Cape Province: Demographics, poverty, income, inequality and unemployment from 2000 till 2007. Background paper series: 1(2). Ellensburg. Cape Town; 2009

[48] Zanoli R. The European consumer and organic food. School of Management and Business, Wales; 2004

[49] Botha L. , Van Schalkwyk H D. Concentration in the South African food retailing industry: proceedings of the 44th annual AEASA conference, September 20 - 22, Grahamstown, South Africa; 2006

[50] Irwin BL. Small-scale previously disadvantaged producers in the South African organic market: Adoption model and institutional approach. Masters' dissertation. Michigan State University, U. S. A; 2002.

[51] Food Safety Agency. FSA: ConsumerAttitudes. www. food. gov. uk/multimedia / pdfs /casuk05. pdf. (accessed 5 October 2011)

[52] Vermeulen H. , Bienabe E. What about the food 'quality turn' in South Africa? Focus on the organic movement development. paper presented at the 105th EAAE Seminar International Marketing and International Trade of Quality Food Products, March 8-10, Bologna, Italy; 2007.

[53] Briz T, Ward RW. Consumer Awareness of Organic Products in Spain: An Application of Multinomial Logit Models. Food Policy2009 (34) 295-304. 
[54] Organic Trade Association. OTA. Manufacturer Survey. www. ota. com(accessed 10 October 2011).

[55] ZalewskiRI. , Skawi_ska E. Food safety: commodity science point of view. Paper presentation at the International Association of Agricultural Economists Conference, August 12-18, Gold Coast, Australia; 2006 